\title{
OCENA DOSTĘPNOŚCI SYSTEMU PARKINGOWEGO POLITECHNIKI RZESZOWSKIEJ
}

\begin{abstract}
Działalność uczelni uwarunkowana jest wieloma czynnikami. Sa to zarówno czynniki zależne, na które dana jednostka organizacyjna ma wpływ, jak i niezależne, które wynikają $\mathrm{z}$ jej funkcjonowania $\mathrm{w}$ danym otoczeniu. Powszechnie $\mathrm{w}$ ocenie pozycji uczelni na rynku przyjmuje się następujące kryteria: prestiż, innowacyjność, potencjał naukowy, efektywność naukową, warunki studiowania oraz umiędzynarodowienie. W ramach grupy „,warunki studiowania” jednym z ocenianych parametrów jest dostępności obiektów znajdujących się w jej dyspozycji, czyli realna możliwość skorzystania przez studenta $\mathrm{z}$ oferty edukacyjnej. W konsekwencji istotną funkcję pełni efektywny system transportowy, zarówno na poziomie regionalnym (wojewódzkim i międzywojewódzkim), jak i lokalnym (miasta). W strukturze stosowanych przez studentów środków transportów w procesie przemieszczania w relacji stałe miejsce zamieszkania - uczelnia wysoki udział zajmuje motoryzacja indywidualna. Należy podkreślić, że przyjmując kryterium kosztów czy czasu przejazdu, publiczne środki transportu mają jedynie charaktery substytucyjny i niekonkurencyjny w stosunku do motoryzacji indywidualnej. Stosowane środki transportu przez studentów określają wymagania względem infrastruktury. W konsekwencji na terenie uczelni ważną funkcję pełni system parkingowy. Celem artykułu jest ocena ilościowa i jakościowa systemu parkingowego Politechniki Rzeszowskiej.
\end{abstract}

Słowa kluczowe: parking, infrastruktura, transport, Rzeszów

\section{WPROWADZENIE}

Politechnika Rzeszowska (PRz) to największa uczelnia techniczna województwa podkarpackiego. Podstawowa infrastruktura uczelni zlokalizowana jest w południowozachodniej części miasta Rzeszowa, a jej rozmieszczenie charakteryzuje się dużą koncentracją. Poszczególne obiekty naukowe, dydaktyczne, administracyjne czy socjalne znajdują się w promieniu kilometra. Pozostałe obejmują Ośrodek Kształcenia Lotniczego w Jasionce, Akademicki Ośrodek Szybowcowy w Bezmiechowej oraz Zamiejscowy Ośrodek Dydaktyczny w Stalowej Woli. Władze uczelni dysponują sześcioma podstawowymi jednostkami organizacyjnymi: Wydziałem Budownictwa i Inżynierii Środowiska; Wydziałem Budowy Maszyn i Lotnictwa; Wydziałem Elektrotechniki i Informatyki; Wydziałem Chemicznym; Wydziałem Matematyki i Fizyki Stosowanej; Wydziałem Zarządzania. W roku akademickim 2011-2012 liczba zatrudnionych pracowników wyniosła 1498, w tym nauczycieli akademickich było $726^{2}$. W tym okresie uczelnia kształciła na 26 kierunkach studiów I, II i III stopnia, w formie studiów stacjonarnych i niestacjonarnych. Liczba studentów kształtowała się na poziomie 16661 osób, w tym 12757 to osoby stu-

\footnotetext{
${ }^{1}$ Zdzisław Jedynak, dr, Wydział Zarządzania, Politechnika Rzeszowska, 35-959 Rzeszów, Al. Powstańców Warszawy 12, tel.: 698400 287, e-mail: zjedynak@prz.edu.pl

${ }^{2}$ Biuletyn Informacji Publicznej Politechniki Rzeszowskiej im. Ignacego Łukasiewicza, http://www.bip.portal. prz.edu.pl (dostęp: 23.05.2012)
} 
diujące stacjonarnie ${ }^{3}$. Na podstawie badań własnych dotyczących studentów kierunku logistyka, w strukturze badanych znaczną część stanowiły osoby pochodzący z miast poniżej 25 tys. mieszkańców oraz wsi, łącznie około 68\%. Natomiast osoby zamieszkujące miasta powyżej 100 tys. w grupie ,studia stacjonarne” stanowiły 17\%, „studia niestacjonarne" zaś - 10\%. W strukturze pokonywanej odległości między stałym miejscem zamieszkania a uczelnią najwyższy udział odnotował przedział $50-100 \mathrm{~km}$ (ok. 40\%). W wypadku studentów studiów niestacjonarnych dodatkowo wysokie miejsce zajął przedział 25-50 km - 28\%. Odległość pokonywaną poniżej $10 \mathrm{~km}$ obejmowała około 10-13\% badanych osób. W konsekwencji całkowity czas podróży z miejsca zamieszkania na uczelnie w przedziale 30-60 minut obejmował 29-41\% studentów, 60-120 minut zaś 31$41 \%$.

Dostęp do poszczególnych obiektów uczelni zlokalizowanych na terenie Rzeszowa zapewnia system transportowy, zarówno na poziomie regionalnym (wojewódzkim i międzywojewódzkim), jak i lokalnym (miasta). Na podstawie badań przeprowadzonych wśród studentów stwierdzono, że system transportowy województwa podkarpackiego i miasta Rzeszów spełnia tylko część stawianych wymagań. Powszechnie stosowanym przez respondentów środkiem transportu w relacji stałe miejsce zamieszkania i uczelnia był samochód osobowy. Warto zwrócić uwagę, że przejazdy samochodem miały głównie charakter łączony (3-5 osób). Dodatkowo w wypadku studentów studiów stacjonarnych wysoki udział w przejazdach codziennych zajmował autobus. Najniższy udział we wszystkich badanych grupach odnotowują środki transportu kolejowego. Natomiast wskazane przez studentów cechy decydujące o wyborze środków transportu to komfort jazdy, bezpieczeństwo oraz szybkość podróżowania. Według przeprowadzonych badań cena w procesie decyzyjnym nie odgrywała istotnej roli. Należy podkreślić, że przyjmując kryterium kosztów czy czasu przejazdu, publiczne środki transportu mają jedynie charaktery substytucyjny, a nie konkurencyjny w stosunku do motoryzacji indywidualnej. Stosowane środki transportu przez studentów określają wymagania względem infrastruktury PRz. W konsekwencji na terenie uczelni ważną funkcję pełni system parkingowy ${ }^{5}$.

Celem artykułu jest ocena ilościowa i jakościowa dostępności systemu parkingowego Politechniki Rzeszowskiej. Dokonano ceny stref parkingowych zlokalizowanych w Rzeszowie przy ulicy Powstańców Warszawy (centralna część PRz, w tym miasteczko akademickie). W badaniach nie uwzględniono obiektów zamiejscowych oraz znajdujących się w Rzeszowie przy ulicy Wincentego Pola. Etapy realizacji celu obejmują: identyfikację struktury systemu parkingowego, rozpoznanie wielkości i struktury wykorzystania poszczególnych stref parkingowych oraz ocenę całościową i częściową systemu parkingowego. Wyznaczono kryteria i wskaźniki oceny badanego systemu. Należy podkreślić, że w pracy podjęto próbę weryfikacji przydatności metody oceny wskaźnikowej do oceny dostępności systemu parkingowego.

\footnotetext{
${ }^{3}$ Ibidem.

${ }^{4}$ Jedynak Z., Romanowska B., Politechnika Rzeszowska a system transportowy województwa podkarpackiego i miasta Rzeszów, Modern Management Review, 20 (4/2013), Rzeszów 2013, s. 95-105.

${ }^{5}$ Ibidem.
} 


\section{IDENTYFIKACJA STRUKTURY}

System parkingowy PRz to podsystem większego systemu, czyli rzeszowskiego systemu parkingowego. Z parkingów zlokalizowanych na terenie uczelni korzystają głównie jej pracownicy oraz studenci. Natomiast w ograniczonym stopniu pozostałe strony zainteresowane, to jest pracownicy firm zlokalizowanych na terenie uczelni oraz pacjenci przychodni Medyk. W bliskim otoczeniu PRz mają swoja siedzibę zakłady przemysłowe, jednostki handlowe, kulturowe czy socjalno-bytowe. Jednak strefy parkingowe rozmieszczone na uczelni znajdują się w znacznej odległości od tych obiektów. Ponadto jednostki te mają własne miejsca parkingowe, które zaspokajają ich potrzeby.

Badana infrastruktura systemu parkingowego PRz tworzy głównie parkingi naziemny (tylko budynek będący siedzibą władz PRz ma parking podziemny). Są to obiekty jednopoziomowe, z samodzielnym ruchem pojazdów oraz niestrzeżone. Na potrzeby pomiaru bezpośredniego $\mathrm{w}$ ramach podstawowej infrastruktury uczelni wydzielono dziewięć stref parkingowych. Przeprowadzona inwentaryzacja pozwoliła wyznaczyć całkowitą liczbę miejsc parkingowych na poziomie $1403^{6}$. Charakterystykę stref parkingowych zlokalizowanych przy ulicy Powstańców Warszawy zamieszczono na rysunku 1 oraz w tabeli 1.

Rys. 1. Struktura badanego systemu parkingowego Politechniki Rzeszowskiej

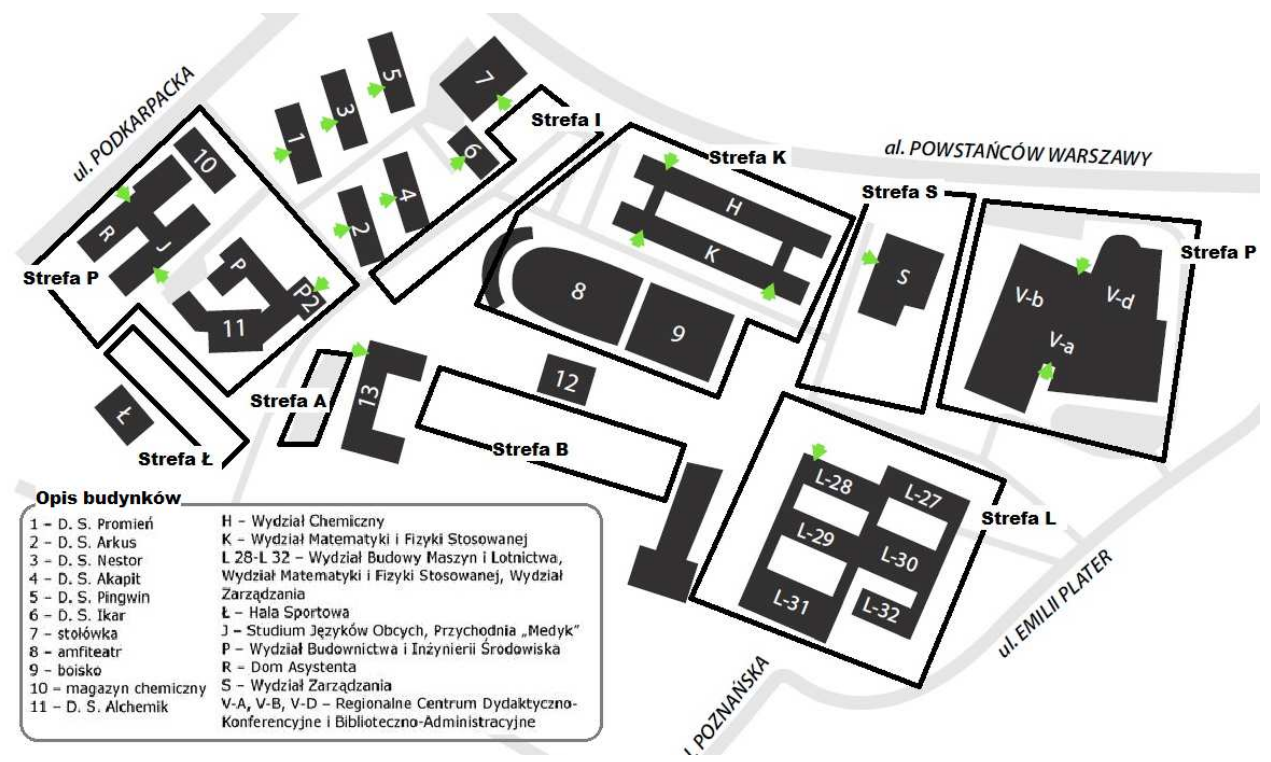

Źródło: opracowanie własne na podstawie: Piotrowska M., Ocena systemu parkingowego Politechniki Rzeszowskiej, praca inżynierska pod kierunkiem Z. Jedynaka, Politechnika Rzeszowska, Rzeszów 2014.

\footnotetext{
${ }^{6}$ M. Piotrowska, Ocena systemu parkingowego Politechniki Rzeszowskiej, praca inżynierska pod kierunkiem Z. Jedynaka, Politechnika Rzeszowska, Rzeszów 2014.
} 
Tabela 1. Liczba miejsc w strefach parkingowych Politechniki Rzeszowskiej

\begin{tabular}{|l|c|c|c|c|c|c|c|c|c|c|}
\hline \multirow{2}{*}{ Rodzaj } & \multicolumn{7}{|c|}{ Strefy parkingowe } & \multirow{2}{*}{ Suma } \\
\cline { 2 - 12 } & $\mathrm{A}$ & $\mathrm{B}$ & $\mathrm{I}$ & $\mathrm{K}$ & $\mathrm{L}$ & $£$ & $\mathrm{P}$ & $\mathrm{S}$ & $\mathrm{V}$ & \\
\hline Liczba miejsc & 82 & 148 & 125 & 198 & 236 & 165 & 181 & 102 & 166 & 1403 \\
\hline Dostęp & - & $\mathrm{Z}$ & - & $\mathrm{Z}$ & $\mathrm{Z}$ & - & - & $\mathrm{Z}$ & $\mathrm{Z}$ & - \\
\hline
\end{tabular}

$\mathrm{Z}$ - strefa parkingowa o ograniczonym dostępie

Źródło: opracowanie własne na podstawie: M. Piotrowska, op. cit.

Badane strefy parkingowe PRz, oznaczone symbolami: L, K i S, stanowią obiekty o ograniczonym dostępie za pomocą zapór sterowanych zdalnie pilotem. Przyjęte rozwiązanie obowiązuje od poniedziałku do piątku w godzinach 7.00-16.00. Liczba wydanych pozwoleń przekracza 900. Wielkość ta obejmuje ponad 64\% wszystkich miejsc parkingowych i stanowi to jedynie 5\% w łącznej liczbie potencjalnych użytkowników (studentów i pracowników). Dodatkowo strefy parkingowe B i V mają wbudowane ograniczenia, które jednak nie są powszechnie stosowane.

\section{POMIAR BEZPOŚREDNI}

Bezpośredni pomiar zaparkowanych pojazdów na badanym terenie PRz był przeprowadzony w 2014 r. przez 7 dni w tygodniu w trzech przedziałach czasowych: 8.00-9.00, 12.00-13.00, 16.00-17.00. Zakres obejmował wszystkie strefy parkingowe przedstawione na rysunku 1. Wyniki bezpośredniego pomiaru oraz ich interpretacja graficzna przedstawiono w tabeli 2 oraz na rysunkach $2-3$.

Tabela 2. Liczba zaparkowanych pojazdów samochodowych na terenie Politechniki Rzeszowskiej

\begin{tabular}{|c|c|c|c|c|c|c|c|c|c|c|c|c|c|c|c|c|c|c|c|c|c|}
\hline \multirow{3}{*}{ Data } & \multirow{3}{*}{$\begin{array}{l}\text { Go- } \\
\text { dziny }\end{array}$} & \multicolumn{18}{|c|}{ Strefa } & \multirow{2}{*}{\multicolumn{2}{|c|}{ Suma }} \\
\hline & & \multicolumn{2}{|c|}{$€$} & \multicolumn{2}{|c|}{$\mathrm{P}$} & \multicolumn{2}{|c|}{ A } & \multicolumn{2}{|c|}{ I } & \multicolumn{2}{|c|}{ K } & \multicolumn{2}{|c|}{ B } & \multicolumn{2}{|c|}{$\mathrm{L}$} & \multicolumn{2}{|c|}{ S } & \multicolumn{2}{|c|}{ V } & & \\
\hline & & $\Sigma$ & $\mathrm{N}$ & $\Sigma$ & $\mathrm{N}$ & $\Sigma$ & $\mathrm{N}$ & $\Sigma$ & $\mathrm{N}$ & $\Sigma$ & $\mathrm{N}$ & $\Sigma$ & $\mathrm{N}$ & $\Sigma$ & $\mathrm{N}$ & $\Sigma$ & $\mathrm{N}$ & $\Sigma$ & $\mathrm{N}$ & $\Sigma$ & $\mathrm{N}$ \\
\hline \multirow{4}{*}{ 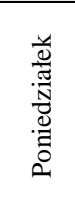 } & $\begin{array}{c}8.00- \\
9.00\end{array}$ & 39 & 0 & 133 & 8 & 44 & 4 & 122 & 4 & 53 & 2 & 96 & 5 & 121 & 5 & 34 & 2 & 91 & 1 & 733 & 31 \\
\hline & $\begin{array}{c}12.00- \\
13.00 \\
\end{array}$ & 117 & 0 & 173 & 20 & 74 & 15 & 128 & 5 & 98 & 1 & 143 & 12 & 158 & 12 & 74 & 3 & 124 & 0 & 1089 & 68 \\
\hline & $\begin{array}{c}16.00- \\
17.00\end{array}$ & 74 & 0 & 153 & 7 & 48 & 9 & 129 & 8 & 42 & 1 & 95 & 7 & 69 & 7 & 25 & 0 & 47 & 0 & 682 & 39 \\
\hline & Suma & 230 & 0 & 459 & 35 & 166 & 28 & 379 & 17 & 193 & 4 & 334 & 24 & 348 & 24 & 133 & 5 & 262 & 0 & 2504 & 137 \\
\hline \multirow{4}{*}{$\begin{array}{l}\frac{y}{0} \\
\stackrel{0}{0} \\
3\end{array}$} & $\begin{array}{c}8.00- \\
9.00\end{array}$ & 61 & 0 & 149 & 9 & 50 & 4 & 133 & 9 & 54 & 0 & 104 & 6 & 156 & 6 & 44 & 5 & 125 & 0 & 876 & 39 \\
\hline & $\begin{array}{c}12.00- \\
13.00\end{array}$ & 89 & 2 & 175 & 23 & 85 & 17 & 130 & 8 & 92 & 1 & 152 & 13 & 187 & 13 & 62 & 6 & 135 & 10 & 1107 & 93 \\
\hline & $\begin{array}{c}16.00- \\
17.00\end{array}$ & 89 & 0 & 169 & 20 & 63 & 7 & 132 & 11 & 34 & 0 & 113 & 3 & 91 & 3 & 22 & 2 & 74 & 1 & 787 & 47 \\
\hline & Suma & 239 & 2 & 493 & 52 & 198 & 28 & 395 & 28 & 180 & 1 & 369 & 22 & 434 & 22 & 128 & 13 & 334 & 11 & 2770 & 179 \\
\hline \multirow{4}{*}{$\begin{array}{l}\frac{\pi}{0} \\
\frac{0}{n}\end{array}$} & $\begin{array}{c}8.00- \\
9.00 \\
\end{array}$ & 69 & 0 & 158 & 12 & 54 & 9 & 131 & 7 & 54 & 0 & 107 & 0 & 140 & 0 & 47 & 5 & 140 & 2 & 900 & 35 \\
\hline & $\begin{array}{c}12.00- \\
13.00 \\
\end{array}$ & 144 & 2 & 183 & 23 & 88 & 20 & 127 & 7 & 101 & 1 & 153 & 16 & 209 & 16 & 70 & 6 & 145 & 11 & 1220 & 102 \\
\hline & $\begin{array}{c}16.00- \\
17.00\end{array}$ & 95 & 0 & 166 & 18 & 80 & 16 & 132 & 11 & 38 & 0 & 120 & 4 & 102 & 4 & 27 & 1 & 56 & 3 & 816 & 57 \\
\hline & Suma & 308 & 2 & 507 & 53 & 222 & 45 & 390 & 25 & 193 & 1 & 380 & 20 & 451 & 20 & 144 & 12 & 341 & 16 & 2936 & 194 \\
\hline$\sigma-$ & $\begin{array}{c}8.00- \\
9.00 \\
\end{array}$ & 75 & 0 & 135 & 3 & 57 & 4 & 126 & 8 & 53 & 0 & 121 & 8 & 147 & 8 & 49 & 4 & 128 & 4 & 891 & 39 \\
\hline
\end{tabular}




\begin{tabular}{|c|c|c|c|c|c|c|c|c|c|c|c|c|c|c|c|c|c|c|c|c|c|}
\hline & $\begin{array}{c}12.00- \\
13.00\end{array}$ & 133 & 0 & 178 & 26 & 88 & 21 & 125 & 5 & 106 & 2 & 155 & 15 & 191 & 15 & 62 & 6 & 149 & 3 & 1187 & 93 \\
\hline & $\begin{array}{c}16.00- \\
17.00\end{array}$ & 83 & 0 & 141 & 10 & 68 & 10 & 118 & 7 & 42 & 2 & 109 & 3 & 73 & 3 & 22 & 4 & 60 & 1 & 716 & 40 \\
\hline & Suma & 291 & 0 & 454 & 39 & 213 & 35 & 369 & 20 & 201 & 4 & 385 & 26 & 411 & 26 & 133 & 14 & 337 & 8 & 2794 & 172 \\
\hline \multirow{4}{*}{ 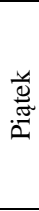 } & $\begin{array}{c}8.00- \\
9.00\end{array}$ & 75 & 0 & 161 & 11 & 60 & 12 & 118 & 4 & 61 & 0 & 93 & 6 & 149 & 6 & 37 & 2 & 113 & 4 & 867 & 45 \\
\hline & $\begin{array}{c}12.00- \\
13.00\end{array}$ & 111 & 0 & 154 & 16 & 60 & 9 & 125 & 4 & 80 & 0 & 116 & 6 & 162 & 6 & 44 & 3 & 142 & 9 & 994 & 53 \\
\hline & $\begin{array}{c}16.00- \\
17.00\end{array}$ & 43 & 0 & 112 & 6 & 33 & 6 & 84 & 1 & 17 & 0 & 48 & 2 & 50 & 2 & 6 & 0 & 65 & 1 & 458 & 18 \\
\hline & Suma & 229 & 0 & 427 & 33 & 153 & 27 & 327 & 9 & 158 & 0 & 257 & 14 & 361 & 14 & 87 & 5 & 320 & 14 & 2319 & 116 \\
\hline \multirow{4}{*}{$\begin{array}{l}\pi \\
0 \\
0 \\
0 \\
\text { is }\end{array}$} & $\begin{array}{c}8.00- \\
9.00\end{array}$ & 44 & 0 & 142 & 6 & 49 & 8 & 88 & 5 & 78 & 3 & 122 & 4 & 143 & 4 & 84 & 13 & 41 & 0 & 791 & 43 \\
\hline & $\begin{array}{c}12.00- \\
13.00\end{array}$ & 100 & 0 & 153 & 19 & 70 & 21 & 97 & 5 & 118 & 9 & 128 & 5 & 141 & 5 & 77 & 12 & 81 & 0 & 965 & 76 \\
\hline & $\begin{array}{c}16.00- \\
17.00\end{array}$ & 62 & 0 & 125 & 8 & 50 & 13 & 78 & 3 & 60 & 3 & 63 & 2 & 54 & 2 & 28 & 3 & 14 & 0 & 534 & 34 \\
\hline & Suma & 206 & 0 & 420 & 33 & 169 & 42 & 263 & 13 & 256 & 15 & 313 & 11 & 338 & 11 & 189 & 28 & 136 & 0 & 2290 & 153 \\
\hline \multirow{4}{*}{$\begin{array}{l}\frac{\pi}{0} \\
\frac{d}{N} \\
\frac{0}{Z}\end{array}$} & $\begin{array}{c}8.00- \\
9.00\end{array}$ & 38 & 0 & 111 & 3 & 26 & 4 & 96 & 1 & 43 & 0 & 84 & 0 & 69 & 0 & 61 & 7 & 55 & 0 & 583 & 15 \\
\hline & $\begin{array}{c}12.00- \\
13.00\end{array}$ & 92 & 1 & 163 & 12 & 66 & 17 & 96 & 1 & 71 & 5 & 115 & 3 & 114 & 3 & 67 & 9 & 32 & 1 & 816 & 52 \\
\hline & $\begin{array}{c}16.00- \\
17.00\end{array}$ & 52 & 0 & 123 & 7 & 55 & 11 & 93 & 2 & 41 & 4 & 37 & 3 & 42 & 3 & 41 & 11 & 14 & 0 & 498 & 41 \\
\hline & Suma & 182 & 1 & 397 & 22 & 147 & 32 & 285 & 4 & 155 & 9 & 236 & 6 & 225 & 6 & 169 & 27 & 101 & 1 & 1897 & 108 \\
\hline
\end{tabular}

$\Sigma$ - całkowita liczba pojazdów, $\mathrm{N}$ - liczba pojazdów nieprawidłowo zaparkowanych

Źródło: opracowanie własne na podstawie: M. Piotrowska, op. cit.

Rys. 2. Struktura zaparkowanych pojazdów samochodowych według strefy na terenie Politechniki Rzeszowskiej

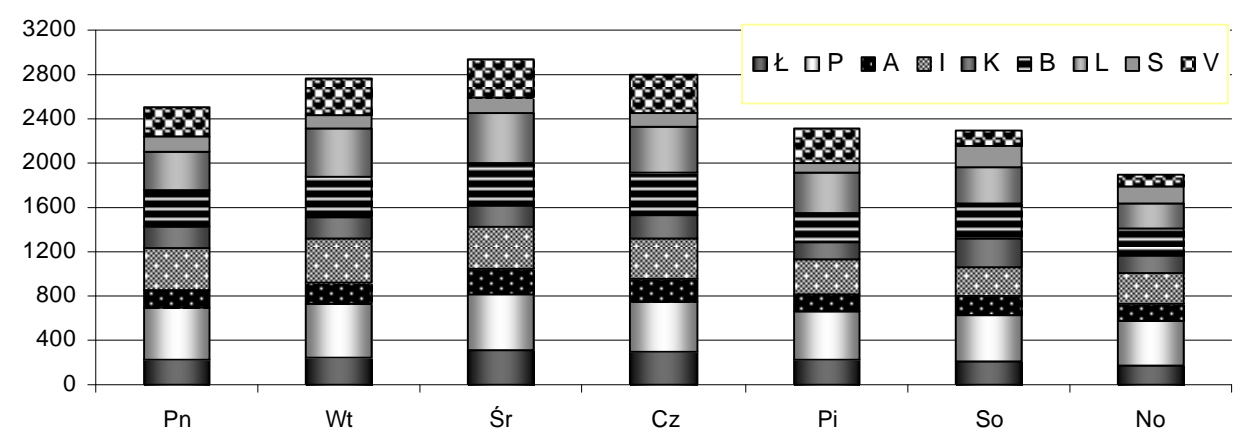

Źródło: opracowanie własne.

Na podstawie bezpośredniego pomiaru ustalono, że średnie dzienne obciążenie badanego systemu parkingowego wynosi 834 pojazdy samochodowe. Znaczną liczbę zaparkowanych pojazdów odnotowano w wtorek, środę i czwartek, niską zaś w piątek, sobotę i niedzielę. Natomiast wstępna analiza wyników pomiaru dla poszczególnych stref parkingowych wskazuje znaczną różnicę w ich obciążeniu. 
Rys. 3. Struktura zaparkowanych pojazdów samochodowych według czasu na terenie Politechniki Rzeszowskiej

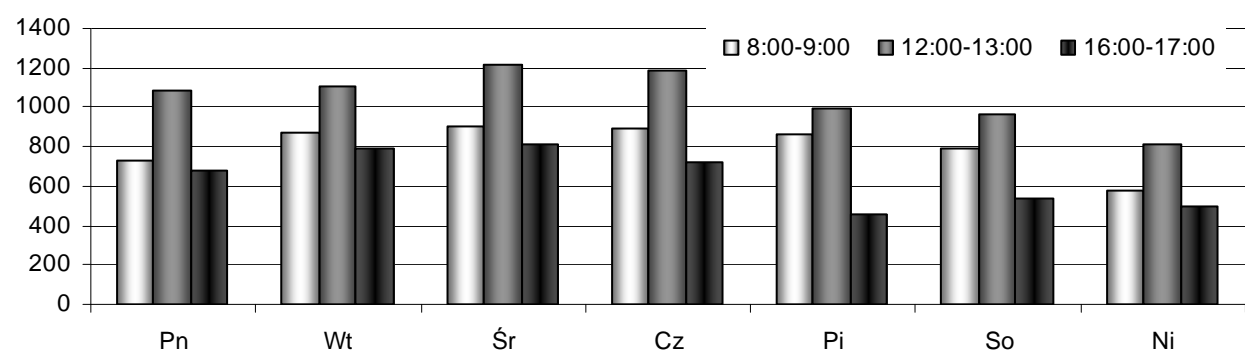

Źródło: opracowanie własne.

Przyjmując kryterium czasu, system parkingowy PRz jest najbardziej obciążony, niezależnie od dnia pomiaru, w godzinach popołudniowych. Najniższy poziom zaś odnotowano w godzinach wieczornych.

\section{OCENA WSKAŹNIKOWA}

Zastosowane w badaniach kryteria i wskaźniki oceny systemu parkingowego PRz przedstawiono w tabeli 4.

Tabela 4. Kryteria i wskaźniki oceny systemu parkingowego

\begin{tabular}{|c|c|c|c|}
\hline Lp. & Nazwa & Wzór & J.m. \\
\hline \multicolumn{4}{|c|}{ A. Kryterium przedmiotowe } \\
\hline 1. & $\begin{array}{l}\text { Wskaźnik udziału strefy } \\
\text { ograniczonego parkowania }\end{array}$ & $\begin{array}{l}\mathrm{W}_{\mathrm{A} 1}=\mathrm{Mo}_{\mathrm{O}} / \mathrm{MC}_{\mathrm{C}} * 100 \\
\mathrm{Mo}_{\mathrm{O}}-\text { liczba miejsc parkingowych objętych } \\
\text { stałym ograniczeniem dostępu; } \mathrm{M}_{\mathrm{C}}-\text { liczba } \\
\text { miejsc parkingowych w badanym okresie }\end{array}$ & $\%$ \\
\hline \multicolumn{4}{|c|}{ B. Kryterium podmiotowe } \\
\hline 1. & Wskaźnik dostępności & $\begin{array}{c}\mathrm{W}_{\mathrm{B} 1}=\mathrm{U}_{\mathrm{C}} / \mathrm{M}_{\mathrm{C}} \\
\mathrm{U}_{\mathrm{C}}-\text { łączna liczba użytkowników parkingu }\end{array}$ & $\begin{array}{l}\text { osoba } \\
\text { / miejsce }\end{array}$ \\
\hline 2. & $\begin{array}{l}\text { Wskaźnik liczby miejsc } \\
\text { parkingowych na } 100 \text { osób }\end{array}$ & $\mathrm{W}_{\mathrm{B} 2}=\mathrm{M}_{\mathrm{C}} / \mathrm{U}_{\mathrm{C}} * 100$ & $\begin{array}{l}\text { miejsce } \\
\text { / } 100 \\
\text { osób }\end{array}$ \\
\hline \multicolumn{4}{|c|}{ C. Kryterium czynnościowe } \\
\hline 1. & Wskaźnik natężenia & $\begin{array}{l}\quad \mathrm{W}_{\mathrm{C} 1}=\mathrm{P}_{\mathrm{n}} / \mathrm{P}_{\mathrm{Cn}} * 100 \\
\mathrm{P}_{\mathrm{n}}-\text { liczba wszystkich zaparkowanych samo- } \\
\text { chodów w danej strefie; } P_{\mathrm{Cn}}-\text { liczba wszystkich } \\
\text { miejsc postojowych w danej strefie }\end{array}$ & $\%$ \\
\hline 2. & Wskaźnik poprawności & $\begin{array}{l}\qquad \mathrm{W}_{\mathrm{C} 2}=\mathrm{P}_{\mathrm{Nn}} / \mathrm{P}_{\mathrm{n}} * 100 \\
\mathrm{P}_{\mathrm{Nn}}-\text { liczba pojazdów źle zaparkowanych } \mathrm{w} \\
\text { danej strefie }\end{array}$ & $\%$ \\
\hline
\end{tabular}

Źródło: opracowanie własne. 
Ocenę wskaźnikową systemu parkingowego PRz przeprowadzono zarówno dla całego systemu, jak i wydzielonych podsystemów. Wyniki oceny przedstawiono w tabelach 5-8.

Tabela 5. Ocena wskaźnikowa systemu parkingowego PRz

\begin{tabular}{|c|c|c|c|c|}
\hline Rodzaj & $\mathrm{W}_{\mathrm{A} 1}$ & $\mathrm{~W}_{\mathrm{B} 1}$ & $\mathrm{~W}_{\mathrm{B} 2}$ & $\mathrm{~W}_{\mathrm{C} 2}$ \\
\hline $\begin{array}{c}\text { System } \\
\text { parkingowy PRz }\end{array}$ & 38,2 & 13,5 & 7,4 & 6,1 \\
\hline
\end{tabular}

Źródło: opracowanie własne.

Tabela 6. Ocena wskaźnikowa systemu parkingowego PRz

\begin{tabular}{|c|c|c|c|c|c|c|c|c|}
\hline \multirow{2}{*}{ Godzina } & \multicolumn{7}{|c|}{ W } & \multicolumn{7}{|c|}{} \\
\cline { 2 - 9 } & Poniedziałek & Wtorek & Środa & Czwartek & Piątek & Sobota & Niedziela & Średnia \\
\hline $\begin{array}{c}8.00- \\
9.00\end{array}$ & 52,2 & 62,4 & 64,1 & 63,5 & 61,8 & 56,4 & 41,6 & 57,4 \\
\hline $\begin{array}{c}12.00- \\
13.00\end{array}$ & 77,6 & 78,9 & 87,0 & 84,6 & 70,8 & 68,8 & 58,2 & 75,1 \\
\hline $\begin{array}{c}16.00- \\
17.00\end{array}$ & 48,6 & 56,1 & 58,2 & 51,0 & 32,6 & 38,1 & 35,5 & 45,7 \\
\hline Średnia & 59,5 & 65,8 & 69,8 & 66,4 & 55,1 & 54,4 & 45,1 & 59,4 \\
\hline
\end{tabular}

Źródło: opracowanie własne.

Analiza wyników oceny wskaźnikowej przeprowadzonej dla całego systemu parkingowego PRz pozwala na sformułowanie następujących wniosków:

- odnotowano wysoki udział strefy ograniczonego parkowania na poziomie $38,2 \%$. Całkowita liczba stref parkingowych objęta stałymi ograniczeniami wynosi 3 , w tym L i K to największe strefy parkingowe zlokalizowane na terenie PRz;

- przyjmując kryterium podmiotowe, liczba użytkowników (pracowników i studentów) przypadająca na 1 miejsce parkingowe wynosi 13,5, natomiast liczba miejsc parkingowych na 100 osób - 7,4. Warto zwrócić uwagę, że całkowita liczba miejsc parkingowych jest niższa od liczby zatrudnionych pracowników PRz. Liczba pracowników PRz stanowi 8,2\% łącznej liczby potencjalnych użytkowników parkingu;

- wskaźnik poprawności zaparkowania dla całego systemu kształtuje się na stosunkowo niskim poziomie $6,1 \%$. Należy podkreślić, że na uczelni brak wydzielonych służb sprawujących bezpośredni nadzór nad poprawnym zaparkowaniem pojazdów;

- wskaźnik natężenia kształtował się na średnim poziomie 59,4\%, co oznacza, że tylko w połowie następowało zapełnienie miejsc parkingowych. Przyjmując dodatkowo kryterium dni, najbardziej obciążona była środa $(69,8 \%)$, najniższy wynik zaś odnotowano w niedzielę $(45,1 \%)$. Natomiast pod względem kryterium czasu najmocniej obciążone były godziny $12.00-13.00$ (75,1\%).

Tabela 7. Ocena wskaźnikowa stref systemu parkingowego Politechniki Rzeszowskiej

\begin{tabular}{|c|c|c|c|c|c|c|c|c|c|c|c|}
\hline \multicolumn{3}{|c|}{ Rodzaj } & $€$ & $\mathrm{P}$ & A & I & K & B & L & S & V \\
\hline \multirow{3}{*}{$\mathrm{W}_{\mathrm{C} 1}$} & \multirow{3}{*}{ م. } & $8.00-9.00$ & 20,0 & 73,5 & 53,7 & 97,6 & 26,8 & 64,9 & 51,3 & 33,3 & 54,8 \\
\hline & & $12.00-13.00$ & 60,0 & 95,6 & 90,2 & 102 & 49,5 & 96,6 & 66,9 & 72,5 & 74,7 \\
\hline & & $16.00-17.00$ & 37,9 & 84,5 & 58,5 & 103 & 21,2 & 64,2 & 29,2 & 24,5 & 28,3 \\
\hline
\end{tabular}




\begin{tabular}{|c|c|c|c|c|c|c|c|c|c|c|}
\hline & Średnia & 39,3 & 84,5 & 67,5 & 101 & 32,5 & 75,2 & 49,2 & 43,5 & 52,6 \\
\hline \multirow{4}{*}{ 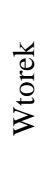 } & $8.00-9.00$ & 31,3 & 82,3 & 61,0 & 106 & 27,3 & 70,3 & 66,1 & 43,1 & 75,3 \\
\hline & $12.00-13.00$ & 45,6 & 96,7 & 104 & 104 & 46,5 & 103 & 79,2 & 60,8 & 81,3 \\
\hline & $16.00-17.00$ & 45,6 & 93,4 & 76,8 & 106 & 17,2 & 76,4 & 38,6 & 21,6 & 44,6 \\
\hline & Średnia & 40,9 & 90,8 & 80,5 & 105 & 30,3 & 83,1 & 61,3 & 41,8 & 67,1 \\
\hline \multirow{4}{*}{ 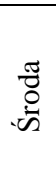 } & $8.00-9.00$ & 35,4 & 87,3 & 65,9 & 105 & 27,3 & 72,3 & 59,3 & 46,1 & 84,3 \\
\hline & $12.00-13.00$ & 73,8 & 101 & 107 & 102 & 51,0 & 103 & 88,6 & 68,6 & 87,3 \\
\hline & $16.00-17.00$ & 48,7 & 91,7 & 97,6 & 106 & 19,2 & 81,1 & 43,2 & 26,5 & 33,7 \\
\hline & Średnia & 52,6 & 93,4 & 90,2 & 104 & 32,5 & 85,6 & 63,7 & 47,1 & 68,5 \\
\hline \multirow{4}{*}{ 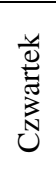 } & $8.00-9.00$ & 38,5 & 74,6 & 69,5 & 101 & 26,8 & 81,8 & 62,3 & 48,0 & 77,1 \\
\hline & $12.00-13.00$ & 68,2 & 98,3 & 107 & 100 & 53,5 & 105 & 80,9 & 60,8 & 89,8 \\
\hline & $16.00-17.00$ & 42,6 & 77,9 & 82,9 & 94,4 & 21,2 & 73,6 & 30,9 & 21,6 & 36,1 \\
\hline & Średnia & 49,7 & 83,6 & 86,6 & 98,4 & 33,8 & 86,7 & 58,1 & 43,5 & 67,7 \\
\hline \multirow{4}{*}{ 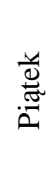 } & $8.00-9.00$ & 38,5 & 89,0 & 73,2 & 94,4 & 30,8 & 62,8 & 63,1 & 36,3 & 68,1 \\
\hline & $12.00-13.00$ & 56,9 & 85,1 & 73,2 & 100 & 40,4 & 78,4 & 68,6 & 43,1 & 85,5 \\
\hline & $16.00-17.00$ & 22,1 & 61,9 & 40,2 & 67,2 & 8,6 & 32,4 & 21,2 & 5,9 & 39,2 \\
\hline & Średnia & 39,1 & 78,6 & 62,2 & 87,2 & 26,6 & 57,9 & 51,0 & 28,4 & 64,3 \\
\hline \multirow{4}{*}{ 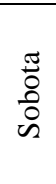 } & $8.00-9.00$ & 22,6 & 78,5 & 59,8 & 70,4 & 39,4 & 82,4 & 60,6 & 82,4 & 24,7 \\
\hline & $12.00-13.00$ & 51,3 & 84,5 & 85,4 & 77,6 & 59,6 & 86,5 & 59,7 & 75,5 & 48,8 \\
\hline & $16.00-17.00$ & 31,8 & 69,1 & 61,0 & 62,4 & 30,3 & 42,6 & 22,9 & 27,5 & 8,4 \\
\hline & Średnia & 35,2 & 77,3 & 68,7 & 70,1 & 43,1 & 70,5 & 47,7 & 61,8 & 27,3 \\
\hline \multirow{4}{*}{$\begin{array}{l}\frac{\pi}{0} \\
\frac{\pi}{0} \\
\frac{\pi}{z} \\
\end{array}$} & $8.00-9.00$ & 19,5 & 61,3 & 31,7 & 76,8 & 21,7 & 56,8 & 29,2 & 59,8 & 33,1 \\
\hline & $12.00-13.00$ & 47,2 & 90,1 & 80,5 & 76,8 & 35,9 & 77,7 & 48,3 & 65,7 & 19,3 \\
\hline & $16.00-17.00$ & 26,7 & 68,0 & 67,1 & 74,4 & 20,7 & 25,0 & 17,8 & 40,2 & 8,4 \\
\hline & Średnia & 31,1 & 73,1 & 59,8 & 76,0 & 26,1 & 53,2 & 31,8 & 55,2 & 20,3 \\
\hline \multicolumn{2}{|c|}{$\mathrm{W}_{\mathrm{C} 2}$} & 0,3 & 8,5 & 18,7 & 4,8 & 2,5 & 5,4 & 4,8 & 10,6 & 2,8 \\
\hline
\end{tabular}

Źródło: opracowanie własne.

Tabela. 8. Ocena wskaźnikowa stref systemu parkingowego Politechniki Rzeszowskiej

\begin{tabular}{|c|c|c|c|c|c|c|c|c|c|c|}
\hline \multicolumn{2}{|c|}{ Rodzaj } & $\mathrm{L}$ & P & A & I & K & B & L & S & V \\
\hline \multirow{4}{*}{$W_{\mathrm{C} 1}$} & $8.00-9.00$ & 29,4 & 78,1 & 59,2 & 93,0 & 28,6 & 70,2 & 56,0 & 49,9 & 59,6 \\
\cline { 2 - 11 } & $12.00-13.00$ & 57,6 & 93,1 & 92,5 & 94,6 & 48,1 & 92,9 & 70,3 & 63,9 & 69,5 \\
\cline { 2 - 11 } & $16.00-17.00$ & 36,5 & 78,1 & 69,2 & 87,5 & 19,8 & 56,5 & 29,1 & 23,9 & 28,4 \\
\cline { 2 - 11 } & Średnia & 41,1 & 83,1 & 73,6 & 91,7 & 32,1 & 73,2 & 51,8 & 45,9 & 52,5 \\
\hline
\end{tabular}

Źródło: opracowanie własne.

Analiza wyników oceny wskaźnikowej przeprowadzonej dla poszczególnych stref systemu parkingowego PRz pozwala na sformułowanie następujących wniosków:

- najbardziej obciążone parkingi są P oraz I, natomiast najmniejsze natężenie ruchu odnotowano w strefie K i Ł. Najniższe wskaźniki natężenia stwierdzono w parkingach, które są przypisane tylko do jednego budynku. Dodatkowo niski poziom występuje w strefach zamkniętych (do 53\%). 
W wypadku parkingów $\mathrm{P}, \mathrm{A}$, I oraz B najwyższy poziom obciążenia odnotowuje się we wszystkich wydzielonych do badań przedziałach czasowych. Są to obiekty o braku ograniczeń w parkowaniu. Dodatkowo zlokalizowane są w pobliżu dużych obiektów naukowo-dydaktycznych oraz miasteczka akademickiego. W strefach tych odnotowuje się niepożądane zjawisko nieprawidłowego parkowania.

\section{PODSUMOWANIE}

Na podstawie przeprowadzonej oceny wskaźnikowej dostępności systemu parkingowego PRz, pod względem kryterium ilościowego, należy stwierdzić, że w badanym okresie istniejące rozwiązania w pełni zaspokajają zgłaszane potrzeby. Średnie dzienne obciążenie badanego systemu parkingowego wynosi 834 pojazdów samochodowych na 1403 miejsca postojowe. Jednak jeśli przyjąć kryteria jakościowe, to ocena jest niezadowalająca. Z jednej strony w strukturze systemu parkingowego trzy strefy (z dziewięciu) wykazują pełne obciążenie. Są to obiekty o braku ograniczeń w użytkowaniu. W strefach tych odnotowuje się niepożądane zjawisko nieprawidłowego parkowania. Z drugiej zaś występuje wysoki udział strefy ograniczonego parkowania. Warto zwrócić uwagę, że choć liczba wydanych pozwoleń pokrywa liczbę miejsc parkingowych w strefie ograniczonego parkowania, a czas postoju pojazdu w tych strefach jest znacznie wydłużony i najczęściej odzwierciedla godziny pracy pracowników, jednak te parkingi nie są w pełni wykorzystane.

\section{LITERATURA}

[1] Biuletyn Informacji Publicznej Politechniki Rzeszowskiej im. Ignacego Łukasiewicza, http://www.bip.portal. prz.edu.pl (dostęp: 23.05.2012).

[2] Jedynak Z., Romanowska B., Politechnika Rzeszowska a system transportowy województwa podkarpackiego i miasta Rzeszów, ,Modern Management Review” XVIII/20 (2013), s. 95105.

[3] Politechnika Rzeszowska, http://portal.prz.edu.pl (dostęp: 10.02.2014).

[4] Piotrowska M., Ocena systemu parkingowego Politechniki Rzeszowskiej, praca inżynierska pod kier. Z. Jedynaka, Politechnika Rzeszowska, Rzeszów 2014.

\section{ASSESSMENT OF PARKING SYSTEM IN RZESZOW UNIVERSITY OF TECHNOLOGY}

The activities of the university are determined by many internal and external factors. The internal ones are the ones that the enterprise has an impact on and independent ones are the ones which result from its functioning in a given environment. To assess the university position on the market, the following criteria are taken into account: the prestige, innovation, scientific potential, the efficiency of scientific personnel, study conditions and internationalization. Within the group, "study conditions" one of the evaluated parameters is availability of university facilities to students, which means a tangible opportunity for the students to take advantage of the university's educational offer. As a result, a fully efficient transport system, both at the regional level (provincial and inter provincial) and local (city) is an important feature. Currently, when taking students' usage of means of transport in relation: permanent residence - the university into consideration, a high proportion of personal transport is noticeable. It should be emphasized that, in adopting the criterion of cost and travel time, public means of transport have only a substitution character and are not competitive with individual transport. Means of transport used by both the staff and the students 
set out requirements to the university's infrastructure. Consequently, an important function is a full parking system. The aim of the article is the quantitative and qualitative assessment of parking system in Rzeszow University of Technology.

Keywords: car park, infrastructure, transport, Rzeszow

\section{DOI: $10.7862 /$ rz.2015.mmr.35}

Tekst złożono w redakcji: lipiec 2015

Przyjęto do druku: wrzesień 2015 